\title{
"Study of Sex Differences and Interacting effects Sex and Tribal nontribal origin on ego virtues"
}

\author{
Dr Ushakiran Agrawal, \\ Professor (Psychology) Govt D.B. Girls P.G. (Auto) College,Raipur , Chhattisgarh
}

\begin{abstract}
Main objective of the research paper is as follows: To study sex differences in ego virtues. .To study interacting effects of sex and tribal non-tribal origin on each ego virtue. The sample of the present study was of college going 100 males and 100 females of tribal region (Preferably gond tribe) Their age range was from 18 yrs to 23 yrs they were, under graduate and post graduate students. Similarly 100 male sand 100 females of non -tribal region were chosen having the same age group and same educational qualification. Ego virtues Inventory developed by $\operatorname{Dr} R$ D Helode has been used. It is based upon the Erikson's personality theory reflecting psychosocial balance, consisted of 80 items, ten items for measuring each virtue, there are in all 8 virtues to be measured namely hope, will, purpose, competence, fidelity, care and wisdom, sex wise $t$ values were found significant for hope will purpose, competence, fidelity, care and wisdom and insignificant for love, Two way anova was computed for ego virtue will and the $F$ rario was found insignificant at both the levels for culture and significant for sex at .05 level and interaction effect was found insignificant at both the levels culture wise $t$ values insignificant at both levels except for virtue, competence significant at both levels and for care and wisdom significant at .05 levels For studying interacting effects of sex and culture (tribal non-tribal ) origin on each ego virtue two there were two subgroups of subjects one culture wise and another sex wise for hence $2 \times 2$ anova has been found appropriate for this data, for testing homogeneity of variance levene's test was used, $F$ ratio insignificant for culture sex and for interaction of sex and culture(HOPE). Two way anova was computed for ego virtue (WILL )and the $f$ rario was found insignificant at both the levels for culture and significant for sex at .05 level and interaction effect was found insignificant at both the levels shown in the table, Two way anova was computed for ego virtue (PURPOSE) F ratio was found insignificant at culture, sex. and interaction effect was found significant. for virtue (COMPETENCE) the $F$ ratio was found significant for culture and sex at both the levels and interaction effect was insignificant at both the levels, $\boldsymbol{F}$ ratio (FOR FIDELITY) was found significant for culture at both the levels, for sex significant at .05 level and interaction effect was found significant at both the levels. (FOR LOVE) the F ratio was found insignificant for culture sex at both the levels and the interaction effect was also found insignificant, $F$ ratio has been found significant for culture and sex in CARE and WISDOM.
\end{abstract}

\section{Introduction}

The term personality comes from Latin word Persona meaning mask. According to Greeks the actor wore masks to hide their identity and to enable them to represent the character they were depicting in the play . This dramatic technique was later adopted by the Romans and from them we get our modern term personality .The Romans persona meant "as one appears to others not one actually is". From this connotation of the word persona our popular idea of personality has been derived.

According to Allport (1961) personality is the dynamic organization within the individual of these psychophysical systems that determine the individuals is unique adjustment to the environment. The term dynamic points up the changing nature of personality it emphasizes that changes can occur in the quality and quantity of a person's behavior . Organization implies that personality is not made up of a number of different traits. One simply added to the other but that they are inter-related. The inter-relationship changes with some traits becoming more dominant and other less so, with changes in the child and in the environments. The psychophysical systems are the habit attitudes values beliefs, emotional states Sentiments and motives which are Psychological in nature but which have a physical basis in the person's neural glandular and general bodily states. These system are not the product of heredity though they are based on hereditary foundations. The psychophysical systems are the motivating forces which determine what kind of adjustment the person will make.

Erikson's theoretical formulation proceeds by stages, Eight in all according to Erikson's time table first four stages occur during infancy and childhood fifth stage during adolescent and the last 3 stages during the adult yrs up to and including old age. In Erikson's writings particular emphasis is placed on adolescent period because it is them that the transition between childhood and Adulthood is made what happens in this stage is of greatest significance for adult personality. Identity crisis and identity confusion are undoubtedly the most 
familiar of Eriksonian's concepts. Erikson has been described as an ego psychologist studying the stages of development spanning the entire life span. Each of Erikson's stages of psychosocial development are marked by a conflict for which successful resolution results in a favorable outcome for example trust vs mistrust and by important event that this conflict resolves itself around for example meaning of one's life. Favorable outcome s of each stage are sometimes known as Virtues a term used, in context of Erikson an work as it is implied to medicines meaning potencies. e.g. the virtue that would emerge from successful resolution. Erikson's research suggests that each individual must learn how to hold both extremes of each life stage challenge in tension with one another ,not rejecting one end of tension or the other. only when both extremes in a life stage are understood and accepted as both required and useful, can the optimal virtue for that stage surface. thus trust and mistrust must both be understood and accepted in order for realistic hope to emerge as a viable solution at the first stage. The Erikson's life stage virtues called ego virtues.

Erikson was a Neo-Freudian. He has been described as an "ego psychologist" studying the stages of development, spanning the entire lifespan. Each of Erikson's stages of psychosocial development are marked by a conflict, for which successful resolution will result in a favorable outcome, for example, trust vs. mistrust, and by an important event that this conflict resolves itself around, for example, the meaning of one's life.

Favorable outcomes of each stage are sometimes known as "virtues", a term used, in the context of Erikson an work, as it is applied to medicines, meaning "potencies." Erikson's research suggests that each individual must learn how to hold both extremes of each specific life-stage challenge in tension with one another, not rejecting one end of the tension or the other. Only when both extremes in a life-stage challenge are understood and accepted as both required and useful, can the optimal virtue for that stage surface. Thus, 'trust' and 'mistrust' must both be understood and accepted, in order for realistic 'hope' to emerge as a viable solution at the first stage. Similarly, 'integrity' and 'despair' must both be understood and embraced, in order for actionable 'wisdom' to emerge as a viable solution at the last stage.

The Erikson life-stage virtues, in the order of the stages in which they may be acquired, are:

1. Basic trust vs. basic mistrust - This stage covers the period of infancy. 0-1 year of age. - Whether or not the baby develops basic trust or basic mistrust is not merely a matter of nurture. It is multi-faceted and has strong social components. It depends on the quality of the maternal relationship. The mother carries out and reflects their inner perceptions of trustworthiness, a sense of personal meaning, etc. on the child. If successful in this, the baby develops a sense of trust which "forms the basis in the child for a sense of identity.

2. Autonomy vs. Shame - Covers early childhood - Introduces the concept of autonomy vs. shame and doubt. During this stage the child is trying to master toilet training.

3. Purpose - Initiative vs. Guilt - Preschool / 3-6 years - Does the child have the ability to or do things on their own, such as dress him or herself? If "guilty" about making his or her own choices, the child will not function well. Erikson has a positive outlook on this stage, saying that most guilt is quickly compensated by a sense of accomplishment.

4. Competence - Industry vs. Inferiority - School-age / 6-11. Child comparing self worth to others (such as in a classroom environment). Child can recognize major disparities in personal abilities relative to other children. Erikson places some emphasis on the teacher, who should ensure that children do not feel inferior.

5. Fidelity - Identity vs. Role Confusion - Adolescent / 12 years till 20. Questioning of self. Who am I, how do I fit in? Where am I going in life? Erikson believes that if the parents allow the child to explore, they will conclude their own identity. However, if the parents continually push him/her to conform to their views, the teen will face identity confusion.

6. Intimacy vs. isolation - This is the first stage of adult development. This development usually happens during young adulthood, which is between the ages of 20 to 24 . Dating, marriage, family and friendships are important during the stage in their life. By successfully forming loving relationships with other people, individuals are able to experience love and intimacy. Those who fail to form lasting relationships may feel isolated and alone.

7. Generatively vs. stagnation is the second stage of adulthood and happens between the ages of 25-64. During this time, people are normally settled in their life and know what is important to them. A person is either making progress in their career or treading lightly in their career and unsure about if this is what they want to do for the rest of their working lives. Also during this time, a person is enjoying raising their children and participating in activities that gives them a sense of purpose. If a person is not comfortable with the way their life is progressing, they're usually regretful about the decisions and feel a sense of uselessness.

Ego integrity vs. despair. This stage affects the age group of 65 and on. During this time you have reached the last chapter in your life and retirement is approaching or has already taken place. Many people who have 
achieved what was important to them look back on their lives and feel great accomplishment and a sense of integrity. Conversely, those who had a difficult time during middle adulthood may look back and feel a sense of despair. as an evolving work in progress. This summary attempts to show the main points of the Erikson psychosocial crisis theory of human development. More detail follows this overview.

\section{ERIKSON'S LIFE CYCLE COMPARED WITH FREUD}

\begin{tabular}{|c|c|c|c|c|}
\hline 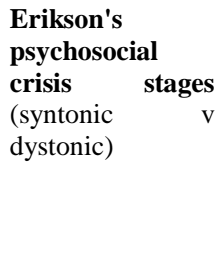 & $\begin{array}{l}\text { Freudian } \\
\text { psycho- } \\
\text { sexual stages }\end{array}$ & $\begin{array}{l}\text { life stage / relationships / } \\
\text { issues }\end{array}$ & $\begin{array}{l}\text { basic virtue and second } \\
\text { named strength (potential } \\
\text { positive outcomes from each } \\
\text { crisis) }\end{array}$ & $\begin{array}{l}\text { maladaptation } \\
\text { malignancy } \\
\text { (potential negative } \\
\text { outcome - one or } \\
\text { the other - from } \\
\text { unhelpful } \\
\text { experience during } \\
\text { each crisis) }\end{array}$ \\
\hline $\begin{array}{l}\text { 1. Trust V } \\
\text { Mistrust }\end{array}$ & Oral & $\begin{array}{l}\text { infant / mother / feeding and } \\
\text { being comforted, teething, } \\
\text { sleeping }\end{array}$ & Hope and Drive & $\begin{array}{l}\text { Sensory Distortion / } \\
\text { Withdrawal }\end{array}$ \\
\hline $\begin{array}{l}\text { 2. Autonomy v } \\
\text { Shame \& Doubt }\end{array}$ & Anal & $\begin{array}{l}\text { toddler / parents / bodily } \\
\text { functions, toilet training, } \\
\text { muscular control, walking }\end{array}$ & Willpower and Self-Control & $\begin{array}{l}\text { Impulsivity } \\
\text { Compulsion }\end{array}$ \\
\hline $\begin{array}{l}\text { 3. Initiative } \mathrm{v} \\
\text { Guilt }\end{array}$ & Phallic & $\begin{array}{l}\text { preschool / family / } \\
\text { exploration and discovery, } \\
\text { adventure and play }\end{array}$ & Purpose and Direction & $\begin{array}{l}\text { Ruthlessness } \\
\text { Inhibition }\end{array}$ \\
\hline $\begin{array}{l}\text { 4. Industry } \mathrm{v} \\
\text { Inferiority }\end{array}$ & Latency & $\begin{array}{l}\text { schoolchild / school, teachers, } \\
\text { friends, neighbourhood / } \\
\text { achievement and } \\
\text { accomplishment }\end{array}$ & Competence and Method & $\begin{array}{l}\text { Narrow Virtuosity / } \\
\text { Inertia }\end{array}$ \\
\hline $\begin{array}{l}\text { 5. Identity v Role } \\
\text { Confusion }\end{array}$ & $\begin{array}{l}\text { Puberty and } \\
\text { Genitality }\end{array}$ & $\begin{array}{l}\text { adolescent / peers, groups, } \\
\text { influences / resolving identity } \\
\text { and direction, becoming a } \\
\text { grown-up }\end{array}$ & Fidelity and Devotion & $\begin{array}{l}\text { Fanaticism } \\
\text { Repudiation }\end{array}$ \\
\hline $\begin{array}{l}\text { 6. Intimacy } \mathrm{v} \\
\text { Isolation }\end{array}$ & (Genitality) & $\begin{array}{l}\text { young adult / lovers, friends, } \\
\text { work connections / intimate } \\
\text { relationships, work and social } \\
\text { life }\end{array}$ & Love and Affiliation & $\begin{array}{l}\text { Promiscuity } \\
\text { Exclusivity }\end{array}$ \\
\hline $\begin{array}{l}\text { 7. Generativity v } \\
\text { Stagnation }\end{array}$ & $\mathrm{n} / \mathrm{a}$ & $\begin{array}{l}\text { mid-adult / children, } \\
\text { community / 'giving back', } \\
\text { helping, contributing }\end{array}$ & Care and Production & $\begin{array}{l}\text { Overextension } \\
\text { Rejectivity }\end{array}$ \\
\hline $\begin{array}{l}\text { 8. Integrity } \mathrm{v} \\
\text { Despair }\end{array}$ & $\mathrm{n} / \mathrm{a}$ & $\begin{array}{l}\text { late adult / society, the world, } \\
\text { life / meaning and purpose, } \\
\text { life achievements }\end{array}$ & Wisdom and Renunciation & $\begin{array}{l}\text { Presumption } \\
\text { Disdain }\end{array}$ \\
\hline
\end{tabular}

Erikson's Life Chart Showing Virtues And Significant Relationship In Different Stages Of Life

\begin{tabular}{|c|c|c|c|c|c|}
\hline $\begin{array}{l}\text { approximate } \\
\text { Age }\end{array}$ & Virtues & Psycho Social Crisis & $\begin{array}{l}\text { Significant } \\
\text { Relationship }\end{array}$ & Existential Question & Examples \\
\hline $2-4$ years & Will & $\begin{array}{l}\text { Autonomy vs. Shame } \\
\text { and Doubt }\end{array}$ & Parents & Is It Okay To Be Me? & $\begin{array}{l}\text { Toilet Training, Clothing } \\
\text { Themselves }\end{array}$ \\
\hline $4-5$ years & Purpose & Initiative vs. Guilt & Family & $\begin{array}{l}\text { Is It Okay For Me To Do, } \\
\text { Move and Act? }\end{array}$ & $\begin{array}{l}\text { Exploring, Using Tools } \\
\text { or Making Art }\end{array}$ \\
\hline $5-12$ years & Competence & $\begin{array}{l}\text { Industry } \\
\text { Inferiority }\end{array}$ & Neighbors, School & $\begin{array}{l}\text { Can I Make It In The World } \\
\text { Of People And Things? }\end{array}$ & School, Sports \\
\hline $13-19$ years & Fidelity & $\begin{array}{l}\text { Identity vs. Role } \\
\text { Confusion }\end{array}$ & Peers, Role Model & Who Am I? What Can I Be? & Social Relationships \\
\hline
\end{tabular}


Study of Sex Differences and Interacting effects Sex and Tribal nontribal origin on ego virtues"

\begin{tabular}{|c|c|c|c|c|c|c|}
\hline $25-64$ years & Care & $\begin{array}{l}\text { Generativity } \\
\text { Stagnation }\end{array}$ & vs. & $\begin{array}{l}\text { Household, } \\
\text { Workmates }\end{array}$ & Can I Make My Life Count? & Work, Parenthood \\
\hline 65-death & Wisdom & $\begin{array}{l}\text { Ego Integrity } \\
\text { Despair }\end{array}$ & & Mankind, My Kind & Is It Okay To Have Been Me? & Reflection on Life \\
\hline
\end{tabular}

On ego identity versus Role Confusion, ego identity enables each person to have a sense of individuality, or as Erikson would say, "Ego identity, then, in its subjective aspect, is the awareness of the fact that there is a selfsameness and continuity to the ego's synthesizing methods and a continuity of one's meaning for others" (1963). Role Confusion, however, is, according to Barbara Englers in her book Personality Theories (2006), "The inability to conceive of oneself as a productive member of one's own society" . This inability to conceive of oneself as a productive member is a great danger; can occur during adolescence when looking for an occupation. Kidwell, Dunham, Bacho, Pastorino and Portes (1995)According to Erikson, exploration is at the heart of the adolescent transition. In his words, exploration is the identity crisis, although crises are not necessarily acute or severe (Erikson, 1959). The remaking of personal identity, which is necessary to complete the transition, was said to be dependent on exploration. In a similar perspective, Grotevant (1987) has referred to exploration as the "work" of the identity process. Erikson has characterized adolescent identity exploration as being accompanied by fluctuations in ego strength. Cognitive de structuring, generally, and the view of the self, in particular, was seen to result in reduced ego strength and impairment of coping. Moreover, a variety of symptoms were said to occur with the transition; these included subjective discomfort, confusion, mood swings, ego defenses, impulsivity, acting-out, and heightened physical and somatic complaints (Erikson, 1956, 1963, 1968). Thus, for Erikson (1968), the self in transition is vulnerable: "Each stage becomes a crisis because incipient growth and awareness in a significant part function goes together with the shift in instinctual energy and yet causes specific vulnerability in that part" (Erikson, 1959, p. 56). Under such a challenge, the experience is one of a "... split of self images, a loss of center, and a dispersion" (Erikson, 1968). These symptoms and the experience of the self as "disrupted" have been described as the "... dark and negative side of identity formation," and they are viewed as vital to the identity process (Erikson, 1975). The present research sought to find empirical evidence concerning Erikson's view that adolescent identity exploration is associated with reduced ego strength and the occurrence of psychological and physical symptoms. While much has been written in an attempt to understand the implications of the "crisis" of adolescence generally, the empirical research has not employed identity exploration as a key variable. Study can be stated as follows: If exploration is the identity crisis, then one would expect an adolescent who scores higher on measures of identity exploration also to show evidence of the symptoms as ascribed by Erikson

In a study by Rae Carlson (2010) It addresses the neglect of work on feminine psychology as a symptom of the far broader impoverishment of contemporary work in personality. Bakan's concepts of agency and communion are invoked toward understanding the constraints imposed by current research paradigms. Agented (masculine) modes of inquiry involving manipulation, quantification, and control need to be complemented by the communal (feminine) research styles (naturalistic, qualitative, open) developed in other disciplines. Three issues are proposed for research in personality: duality in human nature, typology and qualitative patterning and biological bases of personality. These issues are consonant with the nature of feminity, engage the talents of female investigators, and could foster development of the new research paradigms required for serious inquiry in personality. Suggestions for conceptual elaboration and empirical research are proposed.

Haber( 2003),A selective literature review of publications on life review generated ideas on implementation, theory, research, and therapy. The review begins by differentiating life review from reminiscence, and summarizing ways to conduct a life review. A dozen theories that have been influenced by the life review technique are presented, with a focus placed on Erikson's Stages of Psychosocial Development. Erikson's theory has not only been influenced by the life review, it has had a major impact on life review research. Three research topics are discussed: Erikson's ego integrity versus despair in old age, demographical differences in the practice of life reviews, and the impact of conducting life reviews on staff in institutional settings. Most practitioners of life reviews are institutional staff, university students, and family members, many of whom have had limited prior training. The prospect of a certified life review training program is discussed.

Waterman( 19820 )examines, in the light of research findings, those aspects of E. H. Erickson's $(1963,1968)$ theory of psychosocial development that concern the formation of a sense of personal identity. When the Stage 5 component is considered as a bipolar dimension, the expectation is that the transition from adolescence to adulthood involves a progressive strengthening in the sense of identity. When the identity construct is expanded to include the processes by which an identity is formed, it is hypothesized that identity status will change from the identity diffusion status to the foreclosure and then the moratorium status, and from the moratorium to the identity achievement status. The circumstances associated with these changes, regressive changes, and reentry into an identity crisis are discussed. The review of the literature deals with the direction and timing of identity 
development, sex differences in development, and the identification of antecedent conditions relating to the choice of development pathways. (

Marcia (1966 4 modes of reacting to the late adolescent identity crisis were described, measured, and validated. Criteria for inclusion in 1 of 4 identity statuses were the presence of crisis and commitment in the areas of occupation and ideology. Statuses were determined for 86 college male Ss by means of individual interviews. Performance on a stressful concept-attainment task, patterns of goal setting, authoritarianism, and vulnerability to self-esteem change were dependent variables. Ss higher in ego identity performed best on the concept-attainment task; those in the status characterized by adherence to parental wishes set goals unrealistically high and subscribed significantly more to authoritarian values. Failure of the self-esteem condition to discriminate among the statuses was attributed to unreliability in self-esteem measurement. (Psyc INFO Database Record (c) 2012 APA, all rights reserved)

Ethnic identity is central to the psychological functioning of members of ethnic and racial minority groups, but research on the topic is fragmentary and inconclusive. This article is a review of 70 studies of ethnic identity published in refereed journals since 1972. The author discusses the ways in which ethnic identity has been defined and conceptualized, the components that have been measured, and empirical findings. The task of understanding ethnic identity is complicated because the uniqueness that distinguishes each group makes it difficult to draw general conclusions. A focus on the common elements that apply across groups could lead to a better understanding of ethnic identity.

Constructed a self-report questionnaire for measuring the personality components that, according to E. H. Erikson $(1950,1959,1968)$ are formed before the onset of old age. This applied to a sample of 1,859 15 â€" 60 yr old South African White and Black males and females. Results indicate that the reliability of the total scale was high for both Black and White Ss. The reliabilities of the subscales were adequate. Evidence of the validity of the scale is discussed. The components of personality that theoretically develop in childhood seemed strongly interrelated in adolescent and adult Whites. White women appeared to solve the identity crisis earlier, and they experienced a higher degree of intimacy than did White men, although the difference narrowed with age. In both sexes, psychosocial development was related to well-being. Black men seem to resolve the identity crisis only after age 40 yrs and there were indications that the psychosocial development of Black adult women was frustrated. (44 ref) (PsycINFO Database Record (c) 2012 APA, all rights reserved)

Sneed;J.R., Susan; K.W and Michell;E.C, (2008); Studied Erikson's core stages (trust ,identity, and ego integrity) were modeled over 34 years from college through the late 1950s among 175 men and women tested on the Inventory of Psychosocial Development (Constantinople, Dev Psychology 1:357-372, 1969) testing the hypothesis that each, although united by the theme of wholeness and continuity, would show distinct developmental trajectories. Stage 1 (Trust versus Mistrust) followed a positive linear trajectory and Stage 5 (Identity versus Diffusion) followed a curvilinear trajectory that leveled off in middle adulthood. Stage 8 (Ego Integrity versus Despair) followed a curvilinear trajectory with an increasing trend in middle adulthood. The unique trajectories for each of the psychosocial crisis stages were expected on the basis of Erikson's theory. In addition, there was also significant variability in either the mean or slope of each stage demonstrating individual differences in change, a central tenet of Erikson's life span developmental approach.

Franz And Kathleen (2008) studied individuation and attachment in personality development: Extending Erikson's theory ; The question of whether Erikson's theory of psychosocial development is a complete and coherent view of development in males and females is considered. After a thorough review of Erikson's views on the role of sex in psychosocial development, the authors suggest that an important element is neglected in Erikson's account of personality development in both sexes. That is, due to his focus on issues of identity, Erikson does not account fully for the development of intimacy or other expressions of interpersonal attachment. The authors conclude that the major shortcoming of Erikson's theory is not, as some feminists have argued, that it is a male theory but that it fails to account adequately for the processes of interpersonal attachment that are essential to the development of both males and females. Preliminary elements of a two-path model of development are proposed.

Wrightman, L.S. 2009 Studied on Personal documents as data in conceptualizing Adult Personality development this article reviews three differing conceptions of adult personality development the life script approach of Eric Berne Stage theory conceptions of Erik Erikson and Daniel Levinson, and a dialectic approach and describes the knowledge base on which each theory has been evaluated. Various applications of data from personal documents are proposed or described. These include a dialectical reanalysis of letters from jenny the use of presidents auto bio graphics to look at expressed values, and the use of personal documents to generate Social Schemes.

Kidwell, Dunham, Bacho, Pastorino and Portes (1995)According to Erikson, exploration is at the heart of the adolescent transition. In his words, exploration is the identity crisis, although crises are not necessarily acute or severe (Erikson, 1959). The remaking of personal identity, which is necessary to complete the transition, was said to be dependent on exploration. In a similar perspective, Grotevant (1987) has referred to exploration as the 
"work" of the identity process. Erikson has characterized adolescent identity exploration as being accompanied by fluctuations in ego strength. Cognitive destructuring, generally, and the view of the self, in particular, was seen to result in reduced ego strength and impairment of coping. Moreover, a variety of symptoms were said to occur with the transition; these included subjective discomfort, confusion, mood swings, ego defenses, impulsivity, acting-out, and heightened physical and somatic complaints (Erikson, 1956, 1963, 1968).

Thus, for Erikson (1968), the self in transition is vulnerable: "Each stage becomes a crisis because incipient growth and awareness in a significant part function goes together with the shift in instinctual energy and yet causes specific vulnerability in that part" (Erikson, 1959, p. 56). Under such a challenge, the experience is one of a "... split of self images, a loss of center, and a dispersion" (Erikson, 1968). These symptoms and the experience of the self as "disrupted" have been described as the "... dark and negative side of identity formation," and they are viewed as vital to the identity process (Erikson, 1975).

The present research sought to find empirical evidence concerning Erikson's view that adolescent identity exploration is associated with reduced ego strength and the occurrence of psychological and physical symptoms. While much has been written in an attempt to understand the implications of the "crisis" of adolescence generally, the empirical research has not employed identity exploration as a key variable. The general hypothesis of the present study can be stated as follows: If exploration is the identity crisis, then one would expect an adolescent who scores higher on measures of identity exploration also to show evidence of the symptoms as ascribed by Erikson. The sample consisted of 82 academically superior high school students (43 males; 39 females) between 14 and 17 years of age who had completed their junior year. It was comprised of two groups of students attending the Florida State University Summer Science and Mathematics Camp during the summers of 1988 (30 students) and 1989 (52 students). The minimum requirements for admission to the program included percentile ranks of 90 or more on standardized achievement tests, as well as sustained high academic performance. The 1988 and 1989 groups did not differ in measures of socioeconomic status (SES) (Hollingshead, 1965). The SES of the families-of-origin for both groups was middle-to-upper-middle class. The mean SES index was 47.03, with a range of 31-62 for the 1988 sample and a mean of 48.96 with a range of 2966 for the 1989 sample (Hollingshead Four Factor Index of Social Status, 1965). The instruments used were the Minnesota Multiphasic Personality Inventory (MMPI) and the Ego-Identity Interview (Grotevant \& Cooper, 1981). Twenty-three of the commonly used scales of the MMPI were selected to assess symptomatology. There were the nine clinical scales and the 14 Frequently Scored Scales (see Graham, 1987). (Of the ten clinical profile scales, one - Mf, masculinity-femininity - was omitted from the analysis because of its differential norming for males and females.) Adolescent norms were used for scoring the clinical scales (Archer, 1987). Separate adolescent norms were not available for the Frequency Scored Scales.

The Ego-Identity Interview (Grotevant \& Cooper, 1981) was based on Marcia's (1964) operationalization of Erikson's theory (1968) regarding adolescence as a time of increased exploration and commitment. The semistructured interview was designed to gather evidence of exploration and commitment in six domains: occupation, religion, politics, friendships, dating, and sex roles. It examined both the depth and the breadth of exploration which influenced the values, beliefs, and goals of the adolescent. Depth was determined by the number of exploratory activities completed prior to making a commitment. Such activities might include reading about the topic, talking with others, and attending programs. The breadth of exploration was ascertained by the number of alternatives considered (e.g., how many different occupations or religious views considered). Questions also attempted to tap the extent of the "struggle" (e.g., disagreements or conflicts with parents ...

\section{OBJECTIVES}

Main objective of the research paper is as follows:

1. To study sex differences in ego virtues. .

2. To study interacting effects of sex and tribal non-tribal origin on each ego virtue.

Sample :

\section{Methodology}

The sample of the present study was of college going 100 males and 100 females of tribal region (Preferably gond tribe) Their age range was from 18 yrs to 23 yrs they were, under graduate and post graduate students. Similarly 100 male sand 100 females of non -tribal region were chosen having the same age group and same educational qualification .

Tools:

Ego virtues Inventory developed by Dr R D Helode has been used. It is based upon the Erikson's personality theory reflecting psychosocial balance, consisted of 80 items, ten items for measuring each virtue, there are in all 8 virtues to be measured namely hope, will, purpose, competence, fidelity, care and 
wisdom, the split half ( odd-even) reliability of this inventory as well as sub scale wise is as under; for hope scale it is 0.57 , for purpose scale it is 0.59 , for competence scale it is 0.79 , for fidelity scale it is 0.66 , for love scale it is 0.82 , for care scale it is 0.89 , for wisdom scale it is 0,88 and for the whole inventory it is 0.95.

So far as validity is concerned it can be said that this inventory is standing with construct validity as the inter correlations among the scores of eight virtues are statistically insignificant, this observation indicates that each ego virtue comes out separately due to successful resolution of psychosocial crisis of each developmental stage as assumed by Eriksons theory

\section{Procedure:}

Data was collected in small group of five .After establishing rapport with them, then Ego virtues Inventory was administered. And scoring was done.

\section{DATA ANALYSIS ;}

t test was computed to test significant difference among virtues sex wise and culture wise, two way anova was computed to see interacting effects of sex and culture on each ego virtue

\section{Result \& Discussion}

To study sex differences among ego virtues t test was computed and the same is presented in the table below (see table -1)

\begin{tabular}{|c|c|c|c|c|c|}
\hline \multirow[b]{2}{*}{ Virtues } & \multicolumn{5}{|c|}{ 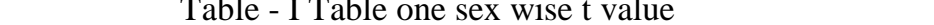 } \\
\hline & Boys Mean & Girls Mean & $t$ value & .05 & .01 \\
\hline \multirow[t]{2}{*}{ Hope } & 6.69 & 5.67 & .096 & 1.97 & 2.60 \\
\hline & SD-1.57 & SD-1.36 & & & \\
\hline \multirow[t]{2}{*}{ Will } & 5.21 & 5.56 & 1.46 & 1.97 & 2.60 \\
\hline & SD-1.77 & SD-1.65 & & & \\
\hline \multirow[t]{2}{*}{ Purpose } & 5.75 & 5.82 & .34 & 1.97 & 2.60 \\
\hline & SD-1.32 & SD-1.37 & & & \\
\hline \multirow[t]{2}{*}{ competence } & 7.69 & 8.23 & 2.33 & 1.97 & 2.60 \\
\hline & SD-1.70 & SD-1.58 & & & \\
\hline \multirow[t]{2}{*}{ Fidelity } & 6.68 & 6.98 & 1.42 & 1.97 & 2.60 \\
\hline & SD-1.50 & SD-1.51 & & & \\
\hline \multirow[t]{2}{*}{ Love } & 6.45 & 6.44 & .057 & 1.97 & 2.60 \\
\hline & SD-1.81 & SD-1.89 & & & \\
\hline \multirow[t]{2}{*}{ Care } & 7.51 & 8.28 & 3.73 & 1.97 & 2.60 \\
\hline & SD-1.64 & SD-1.26 & & & \\
\hline \multirow[t]{2}{*}{ Wisdom } & 6.10 & 6.79 & 3.14 & 1.97 & 2.60 \\
\hline & SD-1.62 & SD-1.47 & & & \\
\hline
\end{tabular}

$t$ value insignificant at both levels except purpose significant at .05 level and for care and wisdom significant at both the levels.

Sex wise interpretation of ego virtues and $t$ values

Hope ; the mean for virtue hope for boys and girls 6.69 and 5.67 respectively, it was more for girls both mean were tested for significance and t value was found 32.98 significant at both the levels at 198 df the difference was due to variation in rearing up practices of boys and girls and child's relationship with mother .

Will ; in this virtue the mean of boys and girls were 5.21 and 5.56 respectively, was more for girls than boys when both the mean were tested for significance using the tool t test, $t$ value computed was 11.29 , significant at both the levels the difference may be due to the vitality and endurance of sex hormone among girls.

Purpose ; the mean among boys and girls in this virtue was 5.75 and 5.82 i.e. more among girls as compared to boys when the means were put to test of significance the $t$ value found was 2.25 significant at .05 level girls have a higher mean because girl has a significant relationship with family hence develop purpose.

Competence ; the mean of this virtue of boys and girls was 7.69 and 8.23 , i.e. higher for girls and lower for boys when it was put to test of significance $t$ value was 17.41 i.e. significant at both the levels, girls were higher on this virtue must have received more encouragement and commendation by parents and teachers hence they developed a feeling of competence more as compared to boys .

Fidelity ; $\mathrm{t}$ value for this ego virtue was 14.28 significant at both the levels the means of boys and girls were 6.68 and 6.98 higher for girls .girls have greater ability of sustaining loyalty.

Love; the mean for boys and girls was found 6.44 and 6.45 and t value 1.05 insignificant at both the levels no significant difference was found among boys and girls in this virtue .

Care ; in this virtue boys have a mean of 7.51 and girls have 8.28 , when tested for significance, $t$ value was fond 24.83 significant at both levels because girls are to be better relationship with home and workmates.

Wisdom ; $\mathrm{t}$ value for this virtue among boys and girls was found to be 38.33 significant at both levels again girls had a higher score of mean because they are more concerned for the mankind. 
To study culture differences among ego virtues, $t$ test was computed and the same is presented in the table below (see table -II)

\begin{tabular}{|c|c|c|c|c|c|}
\hline \multirow[b]{2}{*}{ Virtues } & \multicolumn{4}{|c|}{ Table-II Table one culture wise $t$ value } & \multirow[b]{2}{*}{.01} \\
\hline & Tribal--Mean & $\begin{array}{l}\text { Non tribal -- } \\
\text { Mean }\end{array}$ & $\mathbf{t}$-value & .05 & \\
\hline Hope & $\begin{array}{l}6.57 \\
\text { SD-1,47 }\end{array}$ & $\begin{array}{l}\text { 6.8 } \\
\text { SD-1.45 }\end{array}$ & 1.10 & 1.97 & 2.60 \\
\hline Will & $\begin{array}{l}5.25 \\
\text { SD-1.77 }\end{array}$ & $\begin{array}{l}5.32 \\
\text { SD-1.65 }\end{array}$ & 1.13 & 1.97 & 2.60 \\
\hline Purpose & $\begin{array}{l}\text { 5.78 } \\
\text { SD-1.47 }\end{array}$ & $\begin{array}{l}5.79 \\
\text { SD-1.22 }\end{array}$ & .078 & 1.97 & 2.60 \\
\hline competence & $\begin{array}{l}7.61 \\
\text { SD-1.47 }\end{array}$ & $\begin{array}{l}\text { 8.31 } \\
\text { SD-1.63 }\end{array}$ & 3.20 & 1.97 & 2.60 \\
\hline Fidelity & $\begin{array}{l}6.48 \\
\text { SD-1.66 }\end{array}$ & $\begin{array}{l}7.18 \\
\text { SD-1.35 }\end{array}$ & 3.28 & 1.97 & 2.60 \\
\hline Love & $\begin{array}{l}6.27 \\
\text { SD-1.66 }\end{array}$ & $\begin{array}{l}6.59 \\
\text { SD-1.80 }\end{array}$ & 1.28 & 1.97 & 2.60 \\
\hline Care & $\begin{array}{l}7.60 \\
\text { SD-1.89 }\end{array}$ & $\begin{array}{l}8.19 \\
\text { SD-1.31 }\end{array}$ & 2.53 & 1.97 & 2.60 \\
\hline Wisdom & $\begin{array}{l}6.20 \\
\text { SD-1.64 }\end{array}$ & $\begin{array}{l}6.69 \\
\text { SD-1.45 }\end{array}$ & 2.23 & 1.97 & 2.60 \\
\hline
\end{tabular}

t value insignificant at both levels except for virtue ,competence significant at both levels and for care and wisdom significant at $\mathbf{. 0 5}$ levels .

Hope ; the mean for virtue hope for tribals and non tribals 6.57 and 6.80 respectively, it was more for non tribals both mean were tested for significance and t value was ;found 1.10 insignificant at both the levels at $198 \mathrm{df}$ the difference was due to variation in rearing up practices of tribals and nontribals and child's relationship with mother .

Will ; in this virtue the mean of tribals and non tribals were 5.25 and 5.32 respectively, was more for non tribals than tribals when both the mean were tested for significance using the tool test, $t$ value computed was 1.13 , insignificant at both the levels .

Purpose ; the mean among tribals and non tribals in this virtue was 5.78 and 5.79 , when the means were put to test of significance the $t$ value found was .078 insignificant at both the levels .

Competence ; the mean of this virtue of tribals and nontribals was 7.61 and 8.31 , i.e. higher for non tribals and lower for tribals when it was put to test of significance $t$ value was 3.20 i.e. significant at both the levels, tribals were higher on this virtue must have received more encouragement and commendation by parents and teachers hence they developed a feeling of competence more as compared to tribals .

Fidelity ; $\mathrm{t}$ value for this ego virtue was 3.28 significant at both the levels the means of tribals and nontribals were 6.48 and 7.18 higher for non tribals .non tribals have greater ability of sustaining loyalty.

Love; the mean for tribals and nontribals was found 6.27 and 6.59 and t value 1.28 insignificant at both the levels

Care ; in this virtue tribals have a mean of 7.60 and nontribals have 8.19 , when tested for significance , $t$ value was found 2.53 significant at .05 level.

Wisdom ; $t$ value for this virtue among tribals and nontribals was found to be 2.23 significant at 05 level.

For studying interacting effects of sex and culture (tribal non-tribal ) origin on each ego virtue two there were two subgroups of subjects one culture wise and another sex wise for hence $2 \times 2$ anova has been found appropriate for this data, for testing homogeneity of variance levene's test was used, on these two levels of culture and sex mean of 8 ego virtues hope, will, purpose ,fidelity, love ,care, wisdom were shown homogeneity of variance was tested by levene's test. F value was not significant hence two way anova was computed, sex (male and female) and culture (tribal and non tribal) were independent variables and hope was dependent variable

HOPE

Between subjects factors

\begin{tabular}{|ll|l|l|}
\hline & & Value Label & N \\
\hline Culture & 1 & TRIBAL & 200 \\
& 2 & NON- TRIBAL & 200 \\
Sex & 1 & MALE & 200 \\
& 2 & FEMALE & 200 \\
\hline
\end{tabular}

Dependent Variable: HOPE

\begin{tabular}{|l|l|}
\hline CULTURE $\quad$ SEX & MEAN \\
\hline
\end{tabular}




\begin{tabular}{|ll|l|}
\hline TRIBAL & MALE & $\mathbf{6 . 7 2}$ \\
& FEMALE & $\mathbf{6 . 4 2}$ \\
& Total & $\mathbf{6 . 5 7}$ \\
\hline NON- TRIBAL & MALE & $\mathbf{6 . 6 7}$ \\
& FEMALE & $\mathbf{6 . 9 3}$ \\
& Total & $\mathbf{6 . 8 0}$ \\
\hline Total & MALE & $\mathbf{6 . 6 9}$ \\
& FEMALE & $\mathbf{6 . 6 8}$ \\
& Total & $\mathbf{6 . 6 8}$ \\
\hline
\end{tabular}

Table 4 Homogenity of variance Levene's test

$\begin{array}{llll}\text { F } & \text { df1 } & \text { df2 } & \text { Sig. } \\ 2.044 & 3 & 396 & .107\end{array}$

Dependent Variable: HOPE
\begin{tabular}{|l|l|l|l|l|l|}
\hline Source & $\begin{array}{l}\text { Type III Sum of } \\
\text { Squares }\end{array}$ & Df & Mean Square & F & Sig. \\
\hline Culture & 5.290 & 1 & 5.290 & 2.444 & .119 \\
Sex & .040 & 1 & .040 & .018 & .892 \\
Culture * sex & 7.840 & 1 & 7.840 & 3.622 & .058 \\
Error & 857.140 & 396 & 2.164 & & \\
Corrected Total & 870.310 & 399 & & & \\
\hline
\end{tabular}

a. $\quad$ R Squared $=.015$ (Adjusted R Squared $=.008$ )

b. F ratio insignificant for culture sex and for interaction of sex and culture

WILL Two way anova was computed for ego virtue will and the $f$ rario was found insignificant at both the levels for culture and significant for sex at .05 level and interaction effect was found insignificant at both the levels shown in the table

Dependent Variable: WILL

\begin{tabular}{|c|c|c|}
\hline CULTURE & SEX & MEAN \\
\hline \multirow[t]{3}{*}{ TRIBAL } & MALE & 5.19 \\
\hline & FEMALE & 5.31 \\
\hline & Total & 5.25 \\
\hline \multirow[t]{3}{*}{ NON- TRIBAL } & MALE & 5.23 \\
\hline & FEMALE & 5.82 \\
\hline & Total & 5.52 \\
\hline \multirow[t]{3}{*}{ Total } & MALE & 5.21 \\
\hline & FEMALE & 5.57 \\
\hline & Total & 5.39 \\
\hline
\end{tabular}

Levene's Test of Equality of Error Variances ${ }^{a}$

Dependent Variable:WILL

\begin{tabular}{|l|l|l|l|}
\hline F & df1 & df2 & Sig. \\
\hline 5.165 & 3 & 396 & .002 \\
\hline
\end{tabular}

Tests the null hypothesis that the error variance of the

dependent variable is equal across groups.

Dependent Variable: WILL 


\begin{tabular}{|l|l|l|l|l|l|}
\hline Source & $\begin{array}{l}\text { Type III Sum of } \\
\text { Squares }\end{array}$ & Df & Mean Square & F & Sig. \\
\hline Culture & 7.562 & 1 & 7.562 & 2.540 & .112 \\
Sex & 12.602 & 1 & 12.602 & 4.232 & .040 \\
Culture * sex & 5.522 & 1 & 5.522 & 1.854 & .174 \\
Error & 1179.250 & 396 & 2978 & & \\
& & & & & \\
Corrected Total & 12815.000 & 400 & & & \\
\hline
\end{tabular}

a. $\quad$ R Squared $=.015$ (Adjusted R Squared $=.008)$

\section{PURPOSE}

Two way anova was computed for ego virtue purpose $\mathrm{f}$ ratio was found insignificant at culture , sex .and interaction effect was found significant.

\section{Descriptive Statistics}

Dependent Variable:PURPOSE

\begin{tabular}{|ll|l|}
\hline Culture & sex & Mean \\
\hline TRIBAL & MALE & $\mathbf{5 . 7 8}$ \\
& FEMALE & $\mathbf{5 . 7 8}$ \\
& Total & $\mathbf{5 . 7 8}$ \\
\hline NON- TRIBAL & MALE & $\mathbf{5 . 7 3}$ \\
& FEMALE & $\mathbf{5 . 8 6}$ \\
& Total & $\mathbf{5 . 8 0}$ \\
\hline Total & MALE & $\mathbf{5 . 7 6}$ \\
& FEMALE & $\mathbf{5 . 8 2}$ \\
& Total & $\mathbf{5 . 7 9}$ \\
\hline
\end{tabular}

Levene's Test of Equality of Error Variances ${ }^{\mathrm{a}}$

Dependent Variable:PURPOSE

\begin{tabular}{|l|l|l|l|}
\hline F & df1 & df2 & Sig. \\
\hline 1.399 & 3 & 396 & .243 \\
\hline
\end{tabular}

dependent variable is equal across groups.

a. Design: Intercept + Culture $+\operatorname{sex}+$ Culture $*$ sex

\section{Tests of Between-Subjects Effects}

Dependent Variable:PURPOSE

\begin{tabular}{|l|l|l|l|l|l|}
\hline Source & $\begin{array}{l}\text { Type III Sum of } \\
\text { Squares }\end{array}$ & Df & Mean Square & F & Sig. \\
\hline Culture & .022 & 1 & .022 & .012 & .912 \\
Sex & .422 & 1 & .422 & .230 & .632 \\
Culture * sex & .423 & 1 & .423 & .230 & .632 \\
Error & 728.070 & 396 & 1.839 & & \\
Corrected Total & 728.938 & 399 & & & \\
\hline
\end{tabular}


Tests of Between-Subjects Effects

Dependent Variable:PURPOSE

\begin{tabular}{|l|l|l|l|l|l|}
\hline Source & \multicolumn{1}{l|}{$\begin{array}{l}\text { Type III Sum of } \\
\text { Squares }\end{array}$} & Df & Mean Square & F & Sig. \\
\hline Culture & .022 & 1 & .022 & .012 & .912 \\
Sex & .422 & 1 & .422 & .230 & .632 \\
Culture * sex & .423 & 1 & .423 & .230 & .632 \\
\hline
\end{tabular}

a. R Squared $=.001$ (Adjusted R Squared $=-.006$ )

\section{COMPETENCE}

Two way anova was computed for virtue competence the $\mathrm{F}$ ratio was found significant for culture and sex at both the levels and interaction effect was insignificant at both the levels.

Descriptive Statistics

Dependent Variable:COMPETENCE

\begin{tabular}{|ll|l|}
\hline Culture & sex & Mean \\
\hline TRIBAL & MALE & $\mathbf{7 . 2 2}$ \\
& FEMALE & $\mathbf{8 . 0 0}$ \\
& Total & $\mathbf{7 . 6 1}$ \\
\hline NON- TRIBAL & MALE & $\mathbf{8 . 1 6}$ \\
& FEMALE & $\mathbf{8 . 4 7}$ \\
& Total & $\mathbf{8 . 3 2}$ \\
\hline Total & MALE & $\mathbf{7 . 6 9}$ \\
& FEMALE & $\mathbf{8 . 2 3}$ \\
& Total & $\mathbf{7 . 9 6}$ \\
\hline
\end{tabular}

Levene's Test of Equality of Error Variances ${ }^{a}$

Dependent Variable:COMPETENCE

\begin{tabular}{|l|l|l|l|}
\hline$F$ & df1 & df2 & Sig. \\
\hline 4.150 & 3 & 396 & .007 \\
\hline
\end{tabular}

Tests the null hypothesis that the error variance of the dependent variable is equal across groups.

a. Design: Intercept + Culture + sex + Culture $*$ sex

Tests of Between-Subjects Effects

Dependent

Variable:COMPETENCE

\begin{tabular}{|l|l|l|l|l|l|}
\hline Source & $\begin{array}{l}\text { Type III Sum of } \\
\text { Squares }\end{array}$ & Df & Mean Square & F & Sig. \\
\hline Culture & 49.702 & 1 & 49.702 & 18.065 & .000 \\
Sex & 29.703 & 1 & 29.703 & 10.796 & .001 \\
Culture * sex & 5.522 & 1 & 5.522 & 2.007 & .157 \\
Error & 1089.510 & 396 & 2.751 & & \\
Corrected Total & 1174.437 & 399 & & & \\
\hline
\end{tabular}


FI DELITY F ratio was found significant for culture at both the levels, for sex significant at .05 level and interaction effect was found significant at both the levels.

Levene's Test of Equality of Error Variances ${ }^{a}$

Dependent Variable:FIDELITY

\begin{tabular}{|l|c|c|c|}
\hline F & df1 & df2 & Sig. \\
\hline 2.821 & 3 & 396 & .039 \\
\hline
\end{tabular}

dependent variable is equal across groups.

a. Design: Intercept + Culture + sex + Culture $*$ sex

Tests of Between-Subjects Effects

Dependent Variable:FIDELITY

\begin{tabular}{|l|l|l|l|l|l|}
\hline Source & $\begin{array}{l}\text { Type III Sum of } \\
\text { Squares }\end{array}$ & df & Mean Square & F & Sig. \\
\hline Culture & 49.703 & 1 & 49.703 & 21.554 & .000 \\
Sex & 9.303 & 1 & 9.303 & 4.034 & .045 \\
Culture * sex & 15.603 & 1 & 15.603 & 6.766 & .010 \\
Error & 913.170 & 396 & 2.306 & & \\
Corrected Total & 987.777 & & & & \\
\hline
\end{tabular}

R Squared $=.076$ (Adjusted R Squared $=.069$ )

Love two way anova was computed for

Ego virtue love the $\mathrm{F}$ ratio was found insignificant for culture sex at both the levels and the interaction effect was also found insignificant

Descriptive Statistics

Dependent Variable:LOVE

\begin{tabular}{|ll|l|}
\hline Culture & sex & Mean \\
\hline TRIBAL & MALE & $\mathbf{6 . 3 3}$ \\
& FEMALE & $\mathbf{6 . 2 2}$ \\
& Total & $\mathbf{6 . 2 8}$ \\
\hline NON- TRIBAL & MALE & $\mathbf{6 . 5 2}$ \\
& FEMALE & $\mathbf{6 . 6 6}$ \\
& Total & $\mathbf{6 . 5 9}$ \\
\hline Total & MALE & $\mathbf{6 . 4 3}$ \\
& FEMALE & $\mathbf{6 . 4 4}$ \\
& Total & $\mathbf{6 . 4 3}$ \\
\hline
\end{tabular}

Levene's Test of Equality of Error Variances ${ }^{a}$

Dependent Variable:LOVE

\begin{tabular}{|l|l|l|l|}
\hline$F$ & df1 & df2 & Sig. \\
\hline 1.133 & 3 & 396 & .336 \\
\hline
\end{tabular}

Tests the null hypothesis that the error variance of the

dependent variable is equal across groups.

a. Design: Intercept + Culture + sex + Culture $*$ sex

Tests of Between-Subjects Effects

Dependent Variable: LOVE

\begin{tabular}{|l|l|l|l|l|l|}
\hline Source & $\begin{array}{l}\text { Type III Sum of } \\
\text { Squares }\end{array}$ & Df & Mean Square & F & Sig. \\
\hline Culture & 9.922 & 1 & 9.922 & 2.888 & .090 \\
Sex & .022 & 1 & .022 & .007 & .936 \\
Culture * sex & 1.562 & 1 & 1.562 & .455 & .500
\end{tabular}




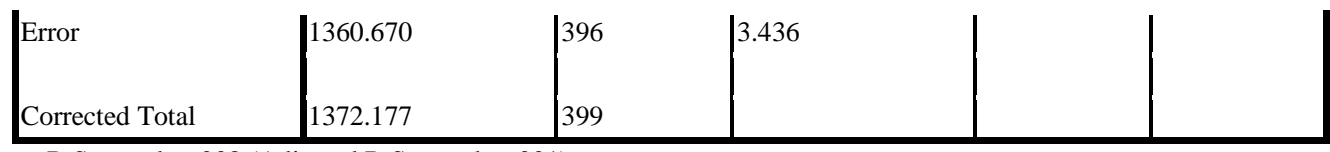

a. R Squared $=.008$ (Adjusted R Squared $=.001)$

Tests of Between-Subjects Effects

Dependent Variable:CARE

\begin{tabular}{|l|l|l|l|l|l|}
\hline Source & $\begin{array}{l}\text { Type III Sum of } \\
\text { Squares }\end{array}$ & & Mean Square & F & Sig. \\
\hline Culture & 34.222 & 1 & 34.222 & 15.750 & .000 \\
Sex & 60.062 & 1 & 60.062 & 27.642 & .000 \\
Culture * sex & .062 & 1 & .062 & .029 & .865 \\
Error & 860.450 & 396 & 2.173 & & \\
Corrected Total & 954.797 & 399 & & & \\
\hline
\end{tabular}

a. $\quad$ R Squared $=.099($ Adjusted R Squared $=.092)$

Descriptive Statistics

Dependent Variable:WISDOM

\begin{tabular}{|ll|l|}
\hline Culture & sex & Mean \\
\hline TRIBAL & MALE & $\mathbf{5 . 8 7}$ \\
& FEMALE & $\mathbf{6 . 5 4}$ \\
& Total & $\mathbf{6 . 2 1}$ \\
\hline NON- TRIBAL & MALE & $\mathbf{6 . 3 4}$ \\
& FEMALE & $\mathbf{7 . 0 5}$ \\
& Total & $\mathbf{6 . 7 0}$ \\
\hline Total & MALE & $\mathbf{6 . 1 0}$ \\
& FEMALE & $\mathbf{6 . 8 0}$ \\
& Total & $\mathbf{6 . 4 5}$ \\
\hline
\end{tabular}

Levene's Test of Equality of Error Variances

Dependent Variable:WISDOM

\begin{tabular}{|l|l|l|l|}
\hline F & df1 & df2 & Sig. \\
\hline 3.049 & 3 & 396 & .029 \\
\hline
\end{tabular}

Tests the null hypothesis that the error variance of the dependent variable is equal across groups.

a. Design: Intercept + Culture + sex + Culture $*$ sex

\section{Descriptive Statistics}

Dependent Variable:CARE

\begin{tabular}{|ll|l|}
\hline Culture & sex & Mean \\
\hline TRIBAL & MALE & $\mathbf{7 . 2 3}$ \\
& FEMALE & $\mathbf{7 . 9 8}$ \\
& Total & $\mathbf{7 . 6 1}$ \\
\hline NON- TRIBAL & MALE & $\mathbf{7 . 7 9}$ \\
& FEMALE & $\mathbf{8 . 5 9}$ \\
& Total & $\mathbf{8 . 1 9}$ \\
\hline Total & MALE & $\mathbf{7 . 5 1}$ \\
& FEMALE & $\mathbf{8 . 2 9}$ \\
& Total & $\mathbf{7 . 9 0}$ \\
\hline
\end{tabular}

Levene's Test of Equality of Error Variances ${ }^{\text {a }}$

Dependent Variable:CARE 


\begin{tabular}{|l|c|c|c|}
\hline F & df1 & df2 & Sig. \\
\hline 5.422 & 3 & 396 & .001 \\
\hline
\end{tabular}

Tests the null hypothesis that the error variance of the dependent variable is equal across groups.

a. Design: Intercept + Culture + sex + Culture $*$ sex

Tests of Between-Subjects Effects

Dependent Variable: WISDOM

\begin{tabular}{|l|l|l|l|l|l|}
\hline Source & $\begin{array}{l}\text { Type III Sum of } \\
\text { Squares }\end{array}$ & df & Mean Square & F & Sig. \\
\hline Culture & 24.010 & 1 & 24.010 & 9.932 & .002 \\
Sex & 47.610 & 1 & 47.610 & 19.694 & .000 \\
Culture * sex & .040 & 1 & .040 & .017 & .898 \\
Error & 957.340 & 396 & 2.418 & & \\
Corrected Total & 1029.000 & 399 & & & \\
\hline
\end{tabular}

a. R Squared $=.070$ (Adjusted R Squared $=.063$ )

\section{Conclusions}

Girls are found to be higher on competence care and wisdom and boys need counseling for the same while counseling for both sexes will be requires on hope, will, purpose ,fidelity and love ,culture wise non tribals are found to be more on fidelity, care and wisdom ego virtues while tribal students need counseling in these virtues, while in hope, will, purpose competence and love both the cultures need counseling.

Fratio has been found in favor of girls in will competence fidelity care and wisdom, in favor of non tribals for competence fidelity care and wisdom .so it is apparent that counseling is requires for hope among both the cultures and sex. It is needed to counsel for virtue will for tribals purpose for both, competence for tribals , fidelity care and wisdom for tribal boys.

\section{References}

[1]. Dallas Hope Melinda Bi rd, (2002). Erikson on Development in Adulthood: New Insights from the Unpublished Papers (Erik Erikson: His Life, Work, and Significance

[2]. Robert S. Wallerstein \& Leo Goldberger, eds. (1998) Andersen, D C (1993), Ideas and Identities: The Life and Work of Erik Erikson "Beyond rumor and reductionism: a textual dialogue with Erik H. Erikson.", The Psychohistory review 22 (1): 35-68,

[3]. J V; Fisher, M W; Sutherland, J D (1971), "Gandhi; a psychoanalytic view. [Essay review of Erik H. Erikson, Gandhi's truth].", The American historical review 76: 1104-15, 1971 Oct,

[4]. Brenman-Gibson, M (1997), "The legacy of Erik Homburger Erikson.", Psychoanalytic review 84 (3): 329-35, 1997 Jun

[5]. Carney, J E (1993), "'Is it really so terrible her?": Karl Menninger's pursuit of Erik Erikson.", The Psychohistory review 22 (1): 11953,

[6]. Coles, R; Fitzpatrick, J J (1976), "The writings of Erik H. Erikson.", The Psychohistory review 5 (3): 42-6, 1976 Dec

[7]. Crunden, R M (1973), "Freud, Erikson, and the historian: a bibliographical survey.", Canadian review of American studies 4 (1): 48 64,

[8]. Douvan, E (1997), "Erik Erikson: critical times, critical theory", Child psychiatry and human development 28 (1): 15-21,

[9]. Eagle, M (1997), "Contributions of Erik Erikson", Psychoanalytic review 84 (3): 337-47, 1997 Jun,

[10]. Fitzpatrick, J J (1976), "Erik H. Erikson and psychohistory", Bulletin of the Menninger Clinic 40 (4): 295-314, 1976 Jul,

[11]. Goethals, G W (1976), "The evolution of sexual and genital intimacy: a comparison of the views of Erik H. Erikson and Harry Stack Sullivan", The Journal of the American Academy of Psychoanalysis 4 (4): 529-44, 1976 Oct,

[12]. Hoffman, L E (1993), "Erikson on Hitler: the origins of 'Hitler's imagery and German youth'", The Psychohistory review 22 (1): 6986 ,

[13]. Masson, J L (1974), "India and the unconscious: Erik Erikson on Gandhi", The International journal of psycho-analysis 55 (4): 519 29

[14]. Roazen, P (1993), "Erik H. Erikson as a teacher", The Psychohistory review 22 (1): 101-17,

[15]. Schnell, R L (1980), "Contributions to psychohistory: IV. Individual experience in historiography and psychoanalysis: significance of Erik Erikson and Robert Coles", Psychological reports 46 (2): 591-612, 1980 Apr,

[16]. Strozier, C B (1976), "Disciplined subjectivity and the psycho historian: a critical look at the work of Erik H. Erikson", The Psychohistory review 5 (3): 28-31, 1976 Dec,

[17]. Weiner, M B (1979), "Caring for the elderly. Psychological aging: aspects of normal personality and development in old age. Part II. Erik Erikson: resolutions of psychosocial tasks", The Journal of nursing care 12 (5): 27-8, 1979 May,

[18]. Wurgaft, L D (1976), "Erik Erikson: from Luther to Gandhi", Psychoanalytic review 63 (2): 209-33,

[19]. Jeannie S. Kidwell, Richard M. Dunham, Roderick A. Bacho, Ellen, Pastorino, Pedro R. Portes; Adolescent Identity Exploration: A Test of Erikson's Theory of Transitional Crisis

[20]. Adolescence, Vol. 30, 1995

[21]. Erik H Erikson 1993 Childhood and Society Publisher: W. W. Norton \& Company; 0002- edition 
[22]. Carol E Franz ${ }^{*}$, Kathleen M White2006 Individuation and attachment in personality development: Extending Erikson's theory Journal of Personality

[23]. Volume 53, Issue 2,pages 224-256, June 1985

[24]. Vital Involvement in Old Age (with J.M. Erikson and H. Kivnick, 1986)

[25]. The Life Cycle Completed (with J.M. Erikson, 1987)

[26]. Adolescent Identity Exploration: A Test of Erikson's Theory of Transitional Crisis ,Journal article by Jeannie S. Kidwell, Richard M. Dunham, Roderick A. Bacho, Ellen Pastorino, Pedro R. Portes; Adolescence, Vol. 30, 1995

[27]. Understanding Women: Implications for Personality Theory and Research ,Rae Carlson Article first published online: 14 APR 2010,DOI: 10.1111/j.1540-4560.1972.tb00015.x1972 The Society for the Psychological Study of Social Issues,Journal of Social Issues

[28]. The International Journal of Aging and Human Development, Issue Volume 63, Number 2 / 2006 Pages 153 - 171,Life Review: Implementation, Theory, Research, and Therapy,David Haber 2003

\section{Carol}

\section{Interdisciplinary Relevance}

The magnitude of eight ego virtues will be assessed and compared sex wise as well as across the tribal non-tribal origins the study will have sociological, cultural, developmental, educational, and counseling interdisciplinary relevance and significance. 